Char: Emerging Markets - Need for a Taxonomy

$\therefore$

IC A

549, CHANA AND AMERICA INSTITUTE
CLARMONT ROAD, SUITE 202 DECATUR, GA 30033 USA

Emerging Harlots Need for a Taxonomy

Sudhanva Char

Journal of Emerging Knowledge on Emerging Markets
Volume 1 Issue 1 


\title{
Emerging Markets - Need for a Taxonomy
}

\author{
Journal of Emerging Knowledge on Emerging Markets \\ Volume 1 Issue 1 \\ November 2009
}

\section{Introduction}

$\mathrm{t}$ the outset the terms 'emerging markets' (EM hereafter) or 'emerging economies'
(EE hereafter) sound familiar to students of development economics. In simplistic
terms, which as we soon see are too skimpy to be acceptable, economies that are set on a path of economic progress or in a transition, and are not any where close to the per capita incomes of developed nations such as USA, Japan, Germany, France, Britain, Italy and such others in the Group of 20 nations, could be regarded as emerging economies with emerging markets. Such an outline of the subject area would be a wooly generalization that could confuse and confound scholars in regard to the scope of the subject. More critically, a one-dimensional income-related criterion would limit the scope of EM or EE as a subject area when in fact it could be an economic Proteus Unbound in terms of potentials for emerging into an interesting subject area. Currently there is no precise definition of either an emerging economy or an emerging market, other than that it is an economy that is striving for a higher standard of living or a market that is burgeoning into a larger and more diversified one. In economics texts standard of living is related to a dollar income.

A taxonomy on which there is a modicum of agreement about EM and EE would help broaden the scope and appeal of the subject while letting it benefit from more intellectual endeavors, rigor and inter-disciplinary maneuverability. In the absence of such an 
intellectual endeavor, there is a danger of 'emerging markets' becoming all things to all people. Sooner there is agreement on the parameters of the subject and earlier we can come up with guidelines in this respect, quicker would be the advances in EE or EM as a field of study in its own right. The unease otherwise is that EM or EE may not emerge as a distinctive topic to accommodate related research. Hence this plea for sorting out topics under emerging markets that would provide an acceptable conceptual framework. Categories and subcategories under an integrated and internally coherent topic would enable a more focused classification, analysis, information recovery and referencing. Coming of age of such a vital topic would then facilitate formulation of sound policies for $\mathrm{EE}$ or EM economic issues.

For purposes of this working paper, however, it is safe to use the terms 'emerging economies', 'emerging markets', and 'middle income countries' as equivalent and interchangeable terms. Till recently the term Third World was used to describe developing economies. The First World was the metaphor to refer to developed countries that were long on capital and short on labor. The Second World consisted of the Soviet Union and others, with a degree of authoritarianism that came under the sway of the Soviet Bloc. When the Soviet Union collapsed in 1991 the term Second World lost its meaning. Also developing countries such as Singapore, Hong Kong, Taiwan, S. Korea, Chile and others (which included countries with military or other forms of statism) were able to achieve per capita incomes bigger than those of several affluent countries. As a result, the First, Second and Third World concepts became outmoded and lacked useful connotation, and indirectly contributed to the spawning of terms like EE and EM.

Then we have Newly Industrialized Countries (NIC) such as Brazil, China, India, Mexico, South Africa, Thailand and others that are getting up to speed in reaching higher standards of living to their people. NIC, as a nomenclature, would not only identify the feature of industries in such economies, but would also overlap with the emerging market countries, as would the "Next Eleven" or N11, which again is a grouping of Bangladesh, Egypt, Indonesia, Iran, South Korea, Mexico, Nigeria, Pakistan, the Philippines, Turkey and Vietnam. Indonesia has a high rating amongst potential investors. ${ }^{i}$ The N11 has emerged as a group possibly because of their promising outlook for growth. One more classification is the G7 or the Group of Seven advanced countries which became G8 when Russia joined. Developing countries including the BRIC (Brazil, Russia, India and China or G4) countries came up with the G20 which has a varying number of more than 20 . This should not be mixed up with another set of G20 consisting of 19 relatively rich countries and a representative from the European Union. ${ }^{\text {ii }}$ A Venn diagram of these groups of countries would have numerous overlaps, such as in Russia which could be found in 3-4 loops. 


\section{World Bank Grouping}

For more practical purposes of this note, three broad World Bank categorizations seem to be pertinent: poor countries, lower and upper middle income countries, and rich countries. Such a classification, based on the Bank's Atlas Method could help better demarcate emerging markets without much of an overlap. Per capita incomes define these limits. In between the richest and the poorest countries are the upper and lower middle income countries some of which are rapidly emerging from poverty, with their markets expanding along with their incomes. More recently, the World Bank has created a different classification of countries based upon their Gross National Income per capita, in place of Gross Domestic Product per capita as hitherto. ${ }^{*}$ Under this category, low income (LI) countries are those with per capita GNI of less than $\$ 975$, lower middle income (LMI) countries are those with incomes between \$976-\$3855, upper middle income (UMI) countries between $\$ 3856-\$ 11,905$, and high income (HI) countries with GNI per capita of over $\$ 11,906$. The income numbers are not water-tight and the World Bank rounds up the numbers to nearest thousand, such as LMI income between $\$ 1000$ and $\$ 4000$. $^{\text {ii }}$

About income-based measures of standard of living or wellbeing, a note of caution is justified. For a long time social scientists have been skeptical about both GDP and per capita income as measures of socioeconomic status, wellbeing or even mortality. They would not accept them as accurate gauges of even simple comfort in life, guaranteeing a safety net of sorts of food, clothing and housing, if nothing else in terms of education, health, nutrition, and continuously increasing standards of living. These circumstances get fuzzier when cross-country income comparisons are undertaken due to lack of agreement about a) essential basket of goods and services for diverse societies, b) costs of living across different countries as well as c) exchange rates usable for conversion to a common dollar currency. ${ }^{\text {iv }}$ In September 2009 in a study commissioned by the French President Nicolas Sarkozy, Joseph Stiglitz and Amartya Sen call for new tools for measuring economic progress that take into account economic welfare of the people, and not just incomes. ${ }^{\mathrm{v}}$ However, the fine-tuning in regard to measures of wellbeing need not delay the progress in EE or EM subject area.

It is easier to say which ones are not emerging markets rather than which are indeed so. 66 countries with per capita incomes higher than $\$ 12,000$ are affluent countries. As a matter of fact, World Bank (2007) data regarding the top ten richest in terms of per capita GDP (in US Dollars) brings up some surprises as follows:

* Gross Domestic Product is the total market value of goods and services within a country in a year. Gross National Income is GDP plus factor incomes earned abroad. 
$\because \prod_{\text {INSTITUTE }}$ EMERging Markets - NeEd for A TAXonomy

\section{Table 1}

\section{Top Ten Affluent Nations}

$\begin{array}{ll}\text { Luxembourg } & 56,380 \\ \text { Norway } & 51,810 \\ \text { Switzerland } & 49,600 \\ \text { USA } & 41,440 \\ \text { Denmark } & 40,750 \\ \text { Iceland } & 37,950 \\ \text { Japan } & 37,050 \\ \text { Sweden } & 35,840 \\ \text { Ireland } & 34,310 \\ \text { UK } & 33,630\end{array}$

Source: http://internationaltrade.suite101.com/article.cfm/world_s_richest_countries

(There are distortions in the per capita income estimates, such as for instance in the case of Luxembourg, and tax havens and financial centers that attract funds, but the rich people making that money live elsewhere.)

Likewise, in the World Bank list mentioned above, there are 43 low income poor countries with incomes of less than $\$ 900$ GNI per capita. The U.N. Human Development Report (2001) lists the poorest countries with incomes of less than $\$ 900$ per capita as Sierra Leone, Tanzania, Burundi, Malawi, Ethiopia, Niger, Guinea-Bissau, Dem. Rep. Congo, Mali and Congo. Located in sub-Saharan Africa, these states get to swing in and out of this list, depending upon adequate rains for farm products, wars and other endemic conflicts both within and regionally with neighbors. Thus Mozambique gets included in the list for 2007, as do Burkina Faso, and the Central African Republic. Windfalls such as oil discovery instantly boost economic status of the smaller markets.

\section{Per Capita Incomes: The Lowest Common Denominator}

Emerging markets exclude the top 66 high income and the bottom 43 low income states. In between are the upper and lower middle class income countries that are emerging from poverty, with their markets expanding along with their incomes. Thus there is a transition from a LI or LMI status to a UMI and HI status. The transitory period earns a nation the epithet of an emerging nation. Thus China, India, Brazil, Argentina, Mexico, almost all of South East Asia, several countries in Eastern Europe, Iran and other Middle East countries, 
South Africa, Egypt and others come under the broad brush label of 'emerging economies' with promising markets even as their per capita incomes increase. At the September 2009 Pittsburg Group of 20 meeting what was significant was the replacement of the Group of 7 (G7) by the G20. This prompted the World Bank President Robert Zoellick to state that "Bretton Woods is being overhauled before our eyes." The voting power within the International Monetary Fund and the World Bank shifted towards the dynamic emergent and developing countries. ${ }^{\mathrm{vi}}$

Having identified emerging markets and portraying some of their economic and/or social characteristics, it would be worthwhile to undertake analytical studies of the main economic, commercial, political, social, cultural and other characteristics of such markets. Such scholarly effort would inform if there is a preponderance of shared rather than exceptional characteristics. In the absence of common features, even other than the lowest common denominator of a given range of incomes, broad brush generalization would be sweeping and inaccurate, retarding scholarly progress. More significantly, EM studies would include both macro and micro aspects of the unique features of the up-and-coming markets. While studies by organizations such as the World Bank, OECD, and individual governments tend to be macro in nature, others by individuals such as by C.K. Prahlad, Tarun Khanna are likely to be micro. Going forward some of these macro and micro features are described in order to provide a flavor of the subtopics of the subject.

\section{Review of Emerging Markets}

The economic delineation above serves as a good starting review of emerging markets. The lower and upper middle income countries defined above would be the entity group with incomes between $\$ 1000$ and $\$ 12,000$. EMs occasionally sway in and out of income classes because of upward and downward per capita income makeovers. World Bank's Independent Evaluation Group (IEG) figures that middle income countries (MIC) number 101 currently as against 83 in 2006. ${ }^{\text {vii }}$ The same source estimates that about $40 \%$ of the world's poor live in MIC, including China and India, or about $33 \%$ without the two. Five out of six African countries belong to the MIC list, whereas it is one in three for Latin America. MICs account for $41 \%$ of the carbon emissions.

China alone accounts for $43 \%$ of MIC (emerging market) population and 25 smallest countries account for a mere $0.3 \%$. The BRIC group includes Russia because despite the $15^{\text {th }}$ or the $16^{\text {th }}$ largest GDP in the world, Russia's per capita GDP is less than $\$ 3000$ ! And the average global per capita GDP is over \$5000! However, in terms of GNI (Purchasing Power Parity) basis it was $\$ 8950$ in 2003. If all these supplementary data were to be included, this survey would be cluttered with copious caveats. To offer an extreme instance, Ian Bremmer even accuses the US, the most developed nation behaving more like an 
emerging market country! ${ }^{\text {viii }}$ The 35\% duty imposed on tires from China in September 2009 and a $36.5 \%$ duty on steel tubes from China in November 2009, are a further evidence of this belittling characterization! $!^{\text {ix }}$ The discordant details here draw attention to the problematic nature of bringing under one subject area diverse nations with some characteristics that are common and others that are singular.

Within the 101 emerging markets, diversity of every nature in their economic, political, social and cultural spheres is too egregious to ignore. Some nation states such as China and India, although still part of the MIC emerging market group as well as of BRIC, are otherwise as different as chalk is from cheese. Their political organization bears out the sharpest contrast, as between an authoritarian construct and an unconstrained democracy, with Russia somewhat in between.

\section{Economic Vulnerability}

In the economic sphere however, the divergences seem to be far less, with both economies offering a free rein to free enterprises and keeping the markets relatively unbound to help businesses achieve their potential and in the process, advance their economies. Be that as it may, the impact of the global economic crisis and the concurrent financial crisis with Wall Street as the epicenter appears to be more hurtful to the Chinese economy than to the Indian economy. This is because of a much higher degree of globalization of the former relative to the latter. Globalization brings in its wake both advantages and turbulence of the world economy regardless of the geographical and political demarcations. One of the macroeconomic observations that needs further investigation is whether an MIC's increased exposure to global markets is an unmixed blessing. What follows elaborates the observation. $40 \%$ Chinese output is destined for the export market, whereas for India it is less than $20 \%$, thus reducing the exposure of the Indian economy and market to global disarray or recession and thus making it less vulnerable to global financial or economic turbulence.

China's heightened vulnerability is because of not just huge commodity exports, but equally importantly on account of its investments of its massive export surpluses in US Government securities, of which $\$ 800$ billion are in Treasury Bonds. It also matters whether the Chinese authorities participate in US Treasury auctions with zeal or apathy, but that is not the concern here. It does though throw light on the new economic and political pressure that a MIC state is able to exert on the world's most powerful economy. The US Government has placated China in financial matters so that Chinese interests are not harmed. The Bush Administration's intervention in Fannie Mae last year when it was collapsing under the weight of sub-prime loans, was, inter alia, influenced by Chinese government phone calls to the US Treasury expressing concern about their investments in Fannie Mae bonds. ${ }^{\mathrm{x}}$ The rationale underlying these details is that there are lessons to be learnt from the policies and programs of any country, either in terms of what policies to emulate and what programs to 
replicate, but also what mistakes to avoid. It is possible that some policies, however much desirable cannot be adopted unless the entire political wherewithal is also borrowed. For example in EC countries, speedy completion of projects is seldom likely without a command-style organization. Similarly, in the case of India it is true that education and training in software programming, mathematics and English have been crucial to progress with Information Technology. Other emerging nations wishing to leapfrog economically need to have the same background to be able to aspire for such progress. In the same setting one may refer to Avinash Dixit's argument that lack of good governance (ensuring property rights including absence of government corruption, enforcement of contracts and collective action) is one of the major causes of poor performance in less-developed and transition economies. ${ }^{\mathrm{xi}}$ Such an administrative infrastructure is a prerequisite for progress.

\section{Perceptions of Progress}

Emergent economies are understandably reluctant to engage themselves in global warming issues at a time when they are preoccupied with economic growth. However, it is not widely appreciated that the cost of growth becomes prohibitive if environmental issues are back-pedaled. What is disagreeable, it creates nuisances or externalities for neighbors. For instance, taking China's case, the nominal rate of growth may be 9\%. However, after accounting for the heavy cost of pollution and related health care costs, World Bank and others suggest that the full cost of such pollution could be about 4 to $5 \%$ and so the net rate of growth is a not so stunning 4 to $5 \%$. No emerging economy can ignore pollution. Even if it is occurring locally, it has global repercussions. Nicholas Stern states that we are all already suffering from past emissions and this is one of the most dramatic market failures and yet there is not much concern or even admission of the dire circumstances. ${ }^{\mathrm{xii}} \mathrm{A}$ somewhat connected but controversial discussion relates to the close association between relatively higher incomes and democracy. This topic of much relevance to emerging economies is professionally dealt with by Acemoglu et al $l^{x i i i}$ and is useful reading for students of EE or EM.

Because of the varied nature of the economies and their markets, caution is needed whenever a broad brush economic overview of the MIC states is attempted. The sheer demographics and the immensity of countries such as China and India, as well as the strategic muscle and sway of a Russia, call for a special perspective in appraisal of their strengths and susceptibilities whether in the environmental, economic, political, social or any other spheres. Public policies in any one of these spheres can have a significant bearing on the markets both for good and bad. This fact can only be ignored at the peril of adding perplexity to the subsets of the subject and sacrificing coherence. 
The microeconomic scene in MIC is as instructive as the macro portrait presented in the preceding paragraphs. What follows are some micro facets of MIC that also serve as the subsets of the EE and EM subject area.

\section{Emerging Market: Where the Rubber Meets the Road}

An innovative idea enhancing the quality of literature on the micro aspects of emerging markets is C.K. Prahlad's "Fortune at the Bottom of the Pyramid" (2006) exhorting market developers to look beyond the superficial inadequacy of purchasing power in the hands of poor masses in developing countries. ${ }^{\text {xiv }}$ Innovation and enterprise would call for catering to this marginalized market. An exceptional example would be microfinance help under Grameen Bank of Mohammed Yunus. Such an endeavor would accomplish several mutually rewarding objectives. First 'Bottom of the Pyramid' endeavors would contribute to raise the standards of living of the millions at the base of the social pyramid. It would tap their entrepreneurial talents that would serve to transform the economic circumstances of the poorest segments. And incredulously, such advances are likely to be engineered by non-profit entrepreneurship rather than by for-profit units. This does not however detract from the appreciable contribution of for-profits in boosting prosperity in emerging markets.

The term 'emerging market' continues to be hot for economists and business persons. There are however surprises when one looks at some micro features of emerging markets. For instance, in the financial area, the term emerging market is not so modern. As a matter of fact, the term is considered archaic because some of the EMs, such as the BRIC group, are growing faster and account for about one half of the world economy. They are loaded with liquidity and corporate and government governance is beginning to look similar to those in the richer economies. Market capitalization in emerging economies is about $30 \%$ of global capitalization, the same share as the USA's. Marko Dimitrijevic's view is that in the coming years it would be inappropriate to treat at least some, if not all, of the EM as a distinct class, and instead they could be treated on par with the developed world for investment purposes. ${ }^{\mathrm{xv}}$

The work of Tarun Khanna and Yishay Yafeh $^{\mathrm{xvi}}$ have strengthened the foundation in the micro areas by exploring the nature of business organizations in emerging markets and in the process they have brought to light valuable data that could help enhance further research. They look at the origin of the diversified groups of business such as Mitsui and Mitsubishi in Japan, Hyundai and Daewoo in S. Korea, Tata and Birla in India, their control structures and growth, their interface with government, and the nature of the markets themselves. They develop the following six remarkable hypotheses about businesses and business groups in the emerging markets: 
1. Diversified business groups should be more common in economies with less developed market institutions.

2. The presence of business groups, the extent of their vertical integration, and the volume of intra-group trade, should all be higher in environments with underdeveloped legal and judicial institutions, where contracting is costly.

3. (a) Pyramidal groups should be particularly common in countries with poor investor protection and inadequate rule of law. (b) These countries should have underdeveloped equity markets because investors will demand a discount when buying shares of companies affiliated with a pyramidal group.

4. (a) Family-controlled groups are likely to be more common in countries with inadequate rule of law, where transactions with outsiders are costly. (b) Family considerations influence the formation, structure and performance of family controlled groups; in some cases, groups may continue to exist for family-related societal reasons, even when they no longer enhance economic efficiency

5. Business groups are formed with government support, expand and diversify with Government nurturing, and their performance is a function of their rent-seeking ability and opportunities

6. (a) Business group formation should involve horizontal mergers, vertical foreclosure, entry deterrence, and other mechanisms designed to increase market power. (b) Monopoly power should be reflected in high profit rates. (c) Group presence should be especially pronounced in environments where monopoly rents can be extracted such as industries and countries with trade barriers and weak antitrust enforcement.

Each one of the hypothesis above has been discussed throwing light on the subject and more importantly, consolidating the literature on the subject. Khanna et al provide the directions for future research. Again a note of caution is warranted when evaluating the worth of capitalist institutions so well presented here. Scholarly work of George and Usha Haley update some aspects of the efforts of Khanna et al, in particular about BusinessGovernment nexus. For instance, in China, according to the Haleys, it is not just labor costs that are lower and help defeat global competition, but "massive government subsidies" play a no less part in such success. ${ }^{\text {vii }}$

Counterbalancing the upbeat account of developmental capitalism is the noteworthy work of Rajan and Zingales: Saving Capitalism from the Capitalist. The two authors contend that contrary to Schumpeter's assertion that capitalism is getting devastated for want of political and social support, what is destroying capitalism is the anti-market tendency of incumbent industrialists and financiers that become too big and eventually monopolies. ${ }^{\text {xiii }}$. This is again a critical thought EM scholars could engage themselves in. 


\section{Agenda for Research}

The classification of topics and subtopics for an internally coherent taxonomy of EE and EM would by itself spawn considerable inquiries, data collection, research and debate that could provide both the contours and contents of the subject matter. There are urgent macro and micro issues challenging conventional economic wisdom that has to be addressed. In the macro area, with the exception of perhaps the Himalayan kingdom of Bhutan where there is a pursuit of happiness, rather than of material consumption, all other countries apparently, would like rapid progress telescoping the decades of development into just few years. The search for a silver bullet continues, and tertiary sector (information technology and services) for instance is preferred to primary (farming and natural resources) and/or secondary (manufacturing) sectors for purposes of leapfrogging from the bullock cart to the modern and avant-garde jet economies. Scholars could look into this aspect of economic growth and verify if indeed there are any magic bullets, or whether the grind and drudge of what was called the "Hindu (sluggish) rate of growth" is inevitable. This author does not believe that any country is predestined to such slow growth, but what cannot be ignored is the marginalization of communities within a society. The exertions of social workers such as Medha Patkar in India are not without a sound rationale. It is a movement to prevent alienation by means of paying a little attention to vulnerable sections of the community. Such marginalization due to rapid development is a common occurrence in numerous emerging countries of Africa, Latin America, Asia, and everywhere else. ${ }^{\text {xix }}$

Globalization is another key development which no emerging market can escape thanks to the rapid progress in transportation, telecommunications and internet technology.

Globalization brings in its wake both good and bad externalities as well as the demonstration effect with attendant imitation issues. For instance an emergent country long on labor, short on capital may wrongly opt for a technology that is short on labor and long on capital. Such a country could even gets its priorities mixed up such as whether safe drinking water should have the first charge on scarce resources or the setting up of a super highway that mostly tourists would avail of.

Other issues that merit inclusion in the agenda for research about EE and EM are:

1 The degree of globalization of emerging economies, their trade flows and patterns, synchronized production for the world markets, futility of decoupling efforts to dodge global recession, financial crisis and such shocks. ${ }^{\mathrm{xx}}$

2 Appropriate response to the challenge of global warming including deciding about a carbon tax or cap and trade, or a out-of-the-box solution 
3 Degree of protection to domestic industry vis-à-vis imports from other low cost developing countries

4 The share of the private and public sectors in total investment

5 The proficient way governance, especially in the public sector without bribery, corruption and kick backs.

6 The kind of planning needed if at all, to take stock of progress and provide guidelines for future advance and evolve new paradigms of development, including model fiscal and monetary policies, if such models are buildable.

7 Ensuring that poor but Emergent economies whose people have less than a dollar a day income are able to achieve the Millennium Development Goals 2015 of halving the number of extreme poor by 2015 by means of, inter alia, universal primary education, gender equality wherever it matters, better health care and so forth. ${ }^{\text {xxi }}$

\section{Conclusion}

A taxonomy to delineate the relatively new concept of emerging market or emerging economy would string together epistemologically homogenous topics. It would help the fuller and faster scholarly growth of the subject, besides enabling the formulation of 'best practices' policy prescriptions for identical problems such as poverty. There is increasing appreciation of the need to eliminate poverty, in particular of the egregious type in emerging markets. The geopolitical weight of such countries has evidently increased. Such clout could enable faster advancement. Areas of emerging market research include both micro and macro aspects of policies and practices relating to defense and security, energy, education, environment, public finance and taxation, governance, health and population, technology, intra and international trade, political and social structure, and cultures. Emerging knowledge about emerging markets would then contribute to push the frontiers of societal advance in a truly global sense.

\section{End Notes}

\footnotetext{
i Stevenson, D. (2009) One emerging market scores a perfect ten, Financial Times, October 16, 2009, retrieved from http://www.ft.com/cms/s/2/428ff2f0-ba78-11de-9dd7-00144feab49a.html

ii Epping, R. (2009) The 21 Century Economy, Vintage Books, New York, p. 291

iii For an income-wide classification of countries and a wealth of other data visit the following World bank site:

http://web.worldbank.org/WBSITE/EXTERNAL/DATASTATISTICS/0,,contentMDK:21725423 pageP K:64133150 piPK:64133175 theSitePK:239419,00.html
} 
${ }^{\text {iv }}$ For a well-reseached and comprehensive paper on the subject see Deaton, A.(2008) Health, Inequality and Economic Development, Journal of Economic Literature, Vol. XLI March 2003, pp. 113-158

v Goodman, P. (2009) Emphasis on Growth is Called Misguided, retrieved on 10/22/09 from http://www.nytimes.com/2009/09/23/business/economy/23gdp.html

${ }^{\text {vi }}$ For an evaluation of the role of emerging markets see he link below retrieved on October 01, 2009: http://www.economist.com/businessfinance/displaystory.cfm?story_id=14558474

${ }^{\text {vii }}$ For an objective analysis and appraisal of progress achieved by MIC and other categories of countries especially in the areas of private sector help, health, nutrition and population, a visit to the following website is rewarding: http://www.ifc.org/ieg

viii Jangijian, V.(2009) The US is Behaving like an Emerging Market Country at the following website retrieved March 21, 2009: http://seekingalpha.com/article/127092-ian-bremmer-u-s-behaving-like-anemerging-market-country

ix http://www.cbp.gov/xp/cgov/trade/trade_programs/duty_rates/advalorem_chinese_tires.xml

${ }^{x}$ For an intriguing account of the China-US interface at the peak of the financial crisis last year see Sanger, D.E. (2009) "US Budget is Scrutinized by Big Creditor" at http://www.nytimes.com/2009/07/29/us/politics/29sanger.html?scp=5\&sq=China\%20Investment $\% 20 \mathrm{in} \%$ 20Treasury\%20Bonds\&st=cse retrieved July 28, 2009

${ }^{x i}$ Dixit, A.(2009) Governance Institutions and Economic Activity (Presidential Address, American Economic Association), American Economic Review 2009, 99-1, pp. 5-24

xii Stern, N. (2008) The Economics of Climate Change, Richard E. Ely Lecture, American Economic Review, Papers and Proceedings, 2008 98/2, pp.1:37

xiii Acemoglu, D. , Johnson, S., Robinson, J. and Yared, P. (2008) Income and Democracy, American Economic Review 2008, 98:3, pp.808-842

xiv Prahlad, C.K. (2006) Competing for the Fortune at the Bottom of the Pyramid (Eradicating Poverty Through Profits), Wharton School Publishing, Pearson Education Inc., Spper Saddle River, NJ

xv For a cogent case against special treatment for business investments in emerging economies, see Dimitrijevic, M (2009) Why the phrase emerging markets no longer applies, Financial Times, September 29, 2009. Retrieved from the following site: http://www.ft.com/cms/s/0/a538f19a-ac90-11de-a754-00144feabdc0.html?nclick_check=1

${ }^{x v i}$ Khanna, T., and Yafeh, Y. (2007) Business Groups in Emerging Markets: Paragons or Parasites? Journal of Economic Literature, June 2007, pp.331-372

xvii Haley, U., and Haley, G. (2008) Subsidies and the China Price, Harvard Business Review, Jun 01, 2008. Prod.\#: F0806C-PDF-ENG

xviii Scylla, R.(2006) Schumpeter Redux: A Review of Raghuram G. Rajan and Luigi Zingales's Saving Capitalism from the Capitalists, Journal of Economic Literature, Vol. XLIV (June 2006), pp. 391-404 


\section{Emerging MARKets - Need for A TAXonomy}

xix For a case of study of economic disregard for certain group of people in India, see Mehta, L (2009) (Editor) Displaced by Development, Confronting Marginalization and Gender Justice, Sage Publications, Los Angeles

${ }^{x x}$ A useful definition of globalization is the one suggested by Fisher, R (2005) Globalization and Monetary Policy, 2008 Annual Report, Federal Reserve Bank of Dallas, TX 7520. Quote: “ Globalization is an ecosystem in which economic potential is no longer defined or contained by political and geographic boundaries. Economic activity knows no bounds in a globalized economy. A globalized world is one where goods, services, financial capital, machinery, money, workers and ideas migrate to wherever they are most valued and can work together most efficiently, flexibly and securely."

${ }^{\text {xxi }}$ For further details of the eight Millennium Development goals visit: http://devdata.worldbank.org/atlas-mdg/ 